\title{
A scoping review of experimental manipulations examining the impact of monetary format on gambling behaviour
}

\author{
Lucas Palmer ${ }^{1}$, Natalie Cringle ${ }^{1}$, Luke Clark $^{1,2}$
}

${ }^{1}$ Centre for Gambling Research at UBC, Department of Psychology, University of British Columbia, Vancouver, B.C., Canada

${ }^{2}$ Djavad Mowafaghian Centre for Brain Health, University of British Columbia, Vancouver, British Columbia, Canada

\section{Address for Correspondence}

Dr Luke Clark, Department of Psychology, University of British Columbia, 2136 West Mall, Vancouver, B.C., V6T 1Z4, Canada. Tel: 001604827 0618. Email: luke.clark@psych.ubc.ca

\section{Funding}

This project was funded by a Discovery Award from the Natural Sciences and Engineering Research Council (Canada) (RGPIN-2017-04069) to Luke Clark, and by the core funding of the Centre for Gambling Research at UBC. NC received an NSERC Undergraduate Summer Research Award. LP holds a UBC Department of Psychology graduate studentship.

\section{Conflict of Interest}

LC is the Director of the Centre for Gambling Research at UBC, which is supported by funding from the Province of British Columbia and the British Columbia Lottery Corporation (BCLC), a Canadian Crown Corporation. The Province of BC government and the BCLC had no role in the initiation, design, or interpretation of the study, and impose no constraints on publishing. LC has received a speaker/travel honorarium from the National Association for Gambling Studies (Australia) and the International Center for Responsible Gaming (US) and has received fees for academic services from the International Center for Responsible Gaming (US), GambleAware (UK) and Gambling Research Exchange Ontario (Canada). He has not received any further direct or indirect payments from the gambling industry or groups substantially funded by gambling. He has provided paid consultancy to, and received royalties from, Cambridge Cognition Ltd. relating to neurocognitive testing. LP and NC have no disclosures.

\section{Acknowledgements}

The authors would like to thank Mario Ferrari and Eve Limbrick Oldfield for helpful input.

\section{Data Availability Statement}

The output data from the database searches conducted for this study, abstract screening, and full-text screening files are openly available in Open-Science Framework (OSF) at [link removed for anonymity].

Abstract (200 words unstructured) 
Gambling involves monetary bets and prizes, but the money can take a range of formats, including cash, chips, ticket-in ticket-out vouchers, and digital options including banking cards. As societies move towards cashless payment for many goods, the question arises of how emerging payment technologies might impact gambling-related harms. We performed a scoping review following PRISMA guidelines to identify research testing the effects of monetary format in gambling. Our eligibility criteria focused on controlled experimental manipulations, to best establish the causal impact of monetary format. We sought to characterize different types of monetary manipulations that have been studied in a gambling context. We identified 19 eligible articles, comprising 23 individual experiments. These experiments were organized according to four distinct manipulations. The most common design (12 experiments), compared gambling under the presence or absence of money. Smaller numbers of experiments were identified manipulating monetary salience, testing Responsible Gambling tools, and testing the impact of promotional inducements. We identified no studies that compared gambling using cash against digital payment forms. Our review highlights a paucity of research testing the possible impact of digital and cashless payment options on gambling related harms, using experimental designs that would permit causal conclusions to be drawn.

\section{Introduction}

Commercial forms of gambling necessarily entail a monetary wager and the possibility of winning a monetary prize. The precise mode of payment for these transactions can vary. Although chips have played a traditional role in casino tables games (e.g. poker, blackjack), most other forms of gambling have relied on cash transactions, such as inserting coins or bills into a slot machine. At around the turn of the century, many jurisdictions began to remove coin trays from slot machines, in favour of 'ticket-in, ticket-out' (TITO) dispensers (Parke et al., 2008). Within this current system, a note (e.g. \$20 bill) is inserted in to the slot machine to initiate the session, but any withdrawn funds are delivered as a ticket or voucher, that can only be converted back to formal money at a cashier's booth. Online gambling, as a major force in the modern gambling landscape, relies on digital payment forms (e.g. deposits into the online account from a debit card, credit card, or via an e-wallet such as PayPal) (Gainsbury \& Blaszczynski, 2020; Haeusler, 2016). Societies are moving towards 'cashless' forms of payment for many goods. This has accelerated during the COVID-19 pandemic, partly due to public health guidance that has discouraged the use of physical cash to reduce virus transmission. Besides the convenience of cashless options to consumers, the advent of card-based payments could facilitate behavioural tracking of gambling involvement, and access to 'responsible gambling' features such as limit-setting tools (Gainsbury \& Blaszczynski, 2020). An outstanding question is whether and how these different monetary formats influence gambling tendencies, and in particular, how these options might exacerbate gambling harms.

A shift towards cashless technologies could increase gambling harms for a number of distinct reasons. Within consumer psychology, research has documented increased spending when customers use cardbased payment methods compared to paying with cash (Banker et al., 2021; Prelec \& Simester, 2001; Soman, 2003.). This 'plastic trap' (Pettit \& Sivanathan, 2011) is particularly observed for indulgent or spontaneous purchases (Thomas et al., 2011) of which gambling could be an example. The effect is often interpreted in relation to the 'pain of paying' hypothesis (Prelec \& Loewenstein, 1998), which states that with cashless or digital payments, the aversive consequences of spending (i.e. losing) money is reduced when the form of payment is less salient, thereby increasing consumption. We note that this 'reduced pain' may arise partly because the gambler does not physically part from any funds, but also because 
the more abstract form of a digital payment may make it harder to keep track of one's spending. In research on gambling, there are other common-sense intuitions that such a move could have negative consequences for people who gamble. For example, the use of cash imposes some inherent constraints on a gambling session: running out of cash creates a break in play and a moment to reflect, from gambling products that can otherwise be highly immersive (Parke, 2008; Stewart \& Wohl, 2013; GREO, 2020). Many casino gamblers describe personal strategies for maintaining control that revolve around their use of cash; for example, to leave one's bank cards at home or in the car, or to only take money into the venue that one is prepared to lose (Rodda et al., 2018), and these strategies would be undermined by alternative forms of payment for gambling.

In starting to organize the research literature on monetary formats in gambling, we conceptualize monetary format as one of a number of broad categories of structural characteristics of gambling products (c.f. Griffiths, 1993; Newall et al., 2021; Parke \& Griffiths, 2006). Structural characteristics are the design features of gambling products (e.g. game speed, sensory feedback) that influence gambling behaviour and, by extension, gambling harms. For example, the 'Asterig' risk assessment tool (Meyer et al., 2011) proposed 10 dimensions and a scoring system, for estimating the harm profile of specific gambling products. Within Asterig, none of the dimensions specifically consider monetary format, although some linkages exist with Asterig dimensions such as 'variable stake size' (i.e. the ability to vary one's bet size within a game). In considering monetary format as a structural characteristic, we note that there are a range of specific product configurations that could be subsumed within this category (see Definitions in Table 1). The payment format may take several forms, including cash, voucher, debit card, or being able to pay on credit (Parke et. al., 2008). There are separate considerations as to how those funds are displayed within a game (e.g. in real-world currency or as in-game points; Ladouceur \& Sévigny, 2009). Some options may be restricted to certain gambling formats, e.g. the use of e-wallets within online gambling (Hauesler et al 2016) or the use of chips in a casino table game (Lapuz \& Griffiths, 2010), and some options may be jurisdictionally specific (e.g. credit card bans in the UK; GREO, 2020).

[Insert Table 1 around here]

The present study is a scoping review of the literature examining monetary format on gambling behaviour. Within psychology, the definitive research design for testing the causal impact of an independent variable (in this case, monetary format) on a dependent variable (gambling behaviour) is a controlled experimental design, in which the experimental condition (e.g. card-based play) is compared against a control condition (Mill, 2011). In considering only experimental designs on the impact of monetary format on gambling, we had two specific objectives. First, what kinds of monetary manipulations have been tested? For this objective, we are seeking to organize existing literature, and identify knowledge gaps; these are standard goals of a scoping review (Munn et al., 2018). Second, informed by this available evidence, what conclusions can be drawn about the likely impact of emerging payment technologies on gambling harm?

\section{Methods}

Our scoping review was initially guided by the Arksey \& O’Malley (2005) five stage procedure for developing scoping reviews. We followed the Preferred Reporting Items for Systematic Reviews and Meta-Analyses (PRISMA) Extension for Scoping Reviews (i.e. PRISMA-ScR, Tricco et al., 2018). We note 
there was a 2020 update to the overall PRISMA reporting guidelines for systematic reviews (Page et al., 2021), but as this update has not yet been tailored specifically for scoping reviews, we have only followed the PRISMA 2020 statement in using its revised flow diagram. Ethics approval was not needed as a literature-based project.

\section{Information Sources and Search Strategy}

To identify relevant documents for the review, the PubMed and Psyclnfo databases were searched from 1990 to September 2020, using the search string (gambl* OR (egm OR electronic gaming machine* OR slot machine* OR structural characteristic*)) AND (money OR monetary OR payment OR cash OR credit OR note acceptors OR bill acceptors OR win*) (exact terminology differs between databases, for exact strings, see Supplementary Material). Search results were exported into Mendeley for organization and screening, which also allowed removal of duplicates. The electronic database searches were supplemented by i) an additional call in February 2021 for relevant articles (including grey literature and unpublished work) made through a post on social media (Twitter) directed to gambling researchers, ii) reference lists of eligible full texts were evaluated for further relevant articles. These supplementary searches yielded 5 and 2 results respectively. The database search was updated in September 2021 to capture recent publications since September 2020. For coverage of relevant grey literature, we used the ProQuest database for dissertations and the Gambling Research Exchange Ontario (GREO) database for government reports, in September 2021 (see Supplementary material for search strings).

Initial title screening was conducted by [anonymized] using Mendeley, which included filtering nonEnglish language publications and non-empirical papers (e.g., commentaries or reviews). Abstract screening was conducted by [anonymized] and [anonymized]: divergent coding was resolved by discussion, referencing the eligibility criteria. Full text screening was conducted by [anonymized]. The number of articles that were captured in the initial search, number of articles remaining after duplicates, and number of articles that were eligible for full text review are outlined in the flow diagram in Figure 1.

[Insert figure 1 around here]

\section{Source Selection and Eligibility Criteria}

Eligibility criteria were defined prior to the title screening, comprising four criteria (summarized here, and reproduced in full in Supplementary Material) and drawing upon the PICO (Patient, Intervention, Comparison, Outcome) for designing systematic reviews: 1) A study must have included a measure of gambling severity (e.g. the South Oaks Gambling Screen, (Lesieur \& Blume, 1987). 2) The study must have employed a gambling scenario that adheres to psychological definitions of gambling (e.g., Reber, 2012), i.e. a bet on a chance outcome for a larger prize. 3) For dependent variables, the study must have measured gambling behaviour (e.g. amount or money bet or number of bets), gambling experience (e.g. self-reported arousal), or physiological measures (e.g. heart rate or brain imaging). 4) For the independent variable, the study must have used an experimental design with at least two conditions (i.e. including a control condition) and employing a monetary manipulation. In keeping with our objective of organizing the available research on monetary manipulations, we did not pre-specify which manipulations would qualify, but we took care to distinguish manipulations of monetary format from related 'structural characteristics' such as the jackpot size or reinforcement rate (which were not considered monetary manipulations). Thus in principle, studies could manipulate the presence of money in a gambling game (e.g. wagering money on a chance outcome versus simply predicting the outcome; 
Abarbanel, 2018), the representation of money within the game, the payment method (e.g. using cash versus some form of credit), or conceivably other manipulations.

\section{Data Charting, Extraction, and Synthesis of Results}

For extracting data from eligible full texts, a data charting form was developed by the research team (see Supplementary Material for data charting form). [anonymized] charted the data from the final documents, and the results were discussed between the team members for the final synthesis and interpretation. Evidence from eligible full text studies is presented in a combination of narrative format and in Table 2. The results are discussed in narrative form by grouping the eligible studies based on the type of manipulation, as determined by the research team after discussing the results of the data extraction.

\section{Results}

The systematic search identified 19 eligible articles (see Figure 1 for PRISMA flow diagram), comprising 23 individual experiments using a monetary manipulation. The 18 experiments could be organized into four categories of monetary manipulations (see Table 2).

[Insert Table 2 around here]

\section{The presence vs absence of money}

The largest category, in which we found 10 articles comprising 12 experiments, were studies comparing gambling for monetary reward against some form of non-monetary control condition. Control conditions varied from playing the identical game for points (e.g Krmpotich, 2016; Ladouceur et al., 2003; Meyer et al., 2000), predicting the game outcomes either with or without trial-by-trial feedback (Roby \& Lumley, 1995), or simply watching the same event without any formal choice or prediction (Wulfert et al., 2008). These studies included a wide range of dependent variables, including subjective arousal (Roby \& Lumley, 1995; Ladouceur et al., 2003), gambling behavioural measures (Krmpotich, 2016; Peterson \& Weatherly, 2011; Weatherly \& Brandt, 2004), and psychophysiological measures, including heart rate (Roby \& Lumley 1995, Meyer et al., 2000, Ladouceur et al., 2003, (Krueger et al., 2005), salivary cortisol as a neuroendocrine index of the stress response (Krueger et al., 2005; Meyer et al., 2000), and brain imaging (Hollander et al., 2005). These studies also included a wide range of gambling formats, including authentic blackjack (Krueger et al., 2005; Meyer et al., 2000), authentic EGMs (Krmpotich, 2016; Ladouceur et al., 2003), simulated EGMs including video poker (Peterson \& Weatherly, 2011; J. Weatherly \& Brandt, 2004), and realistic horse race betting (Wulfert et al., 2005, 2008), as well as a simplified laboratory gambling simulation in Roby \& Lumley (1995).

Notably, across all experiments in this category, at least one of the recorded dependent variables showed a significant effect of the monetary manipulation. In the studies taking physiological or subjective measures of arousal, these differences were consistent in their direction: the availability of monetary reward during gambling was associated with increased arousal. This effect was observed across student participants (Roby \& Lumley 1995, Wulfert et al., 2005, 2008), recreational gamblers (Krueger et al., 2005; Ladouceur et al 2003; Meyer et al., 2000), and people with gambling problems (Hollander et al., 2005). No studies formally tested for differential effects in people with gambling problems: Hollander et al., (2005) did not include a comparison group, and although Krueger et al., 
(2005) included a mixed group of recreational and problem gamblers, individual differences were only examined within the monetary condition.

The three studies that recorded gambling behavioural measures all used student samples and EGM simulations (Krmpotich, 2016; Peterson \& Weatherly, 2011; Weatherly \& Brandt, 2004). Two studies manipulated monetary reward across more than two levels (e.g. a 0, 1 cent, or 10 cent 'exchange rate'), and both studies observed significant reductions in gambling behaviour at higher monetary values (Peterson \& Weatherly, 2011; Weatherly \& Brandt, 2004). A similar pattern was observed in the third study, where a marginally significant effect was found for the monetary reward condition in reducing the amount participants bet per trial relative to the no monetary reward condition. (Krmpotich, 2016). This pattern of cautiousness under monetary availability among non-gamblers is consistent with Roby \& Lumley (1995), in which student participants reported increased arousal but decreased pleasure in the monetary reward condition.

There are some further notable features of the monetary manipulations across these experiments. Most experiments in this category gave participants endowed funds for gambling (see table 1.), but Meyer et al., (2000) and Krueger et al., (2005) were unusual in having blackjack gamblers use their own funds, in a real casino environment. Although we regard this as an important methodological feature, these studies yield qualitatively similar findings to the studies that used endowed funds. Peterson \& Weatherly (2011) included a third monetary condition where instead of a 'per trial' exchange rate for all participants, participants were instructed that one individual with the highest score would receive a $\$ 50$ gift-card. In this study, both the incremental payment and the gift-card conditions were associated with more conservative gambling behaviour, and did not differ from one another. Lastly, the two studies by Wulfert make two notable contributions. First, Wulfert et al., (2008) formally considered gender across two samples: the arousing effect of monetary reward was observed in men and women, with only slight differences in the parametric effects of increasing monetary value, however, this study did not include statistical comparisons by gender. Second, the Wulfert studies clearly demonstrate significant arousal even in the non-monetary control conditions (see also Ladouceur et al 2003). The implication of this finding is that monetary reward amplifies arousal but is not a prerequisite for arousal during gambling.

\section{Manipulating the Saliency of Money}

This category includes 4 studies comprising 6 experiments. In these experiments, all participants gambled for monetary reward, but these studies manipulated the salience (i.e. the psychological emphasis) of the relationship between the gambling outcomes and their associated monetary worth. These salience manipulations took four discrete forms: 1) manipulation of the monetary 'exchange rate' of points, 2) manipulating aspects of the endowed funds such as the physical form of the endowment (Limbrick-Oldfield et al., 2021; McGrath, 2005; Weatherly et al., 2006), 3) emphasizing the monetary value of points in the task instructions, 4) the inclusion of a periodic on-screen reminder of the cash value of the accumulated points (Brandt \& Martin, 2015). The dependent variables in these studies were all behavioural measures of gambling. The gambling format was restricted to one form: EGMs in a laboratory setting, which were simulated EGMs in Weatherly et al. (2006) and Brandt \& Martin (2015), and authentic EGMs in Limbrick-Oldfield et al., (2021)and McGrath (2005). In Weatherly et al. (2006) and Brandt \& Martin (2015), the participants were student samples with low levels of gambling involvement, whereas in Limbrick-Oldfield et al (2021) and McGrath (2005) the participants were experienced slot machine gamblers. 
For the gambling behavioural measures, Weatherly et al., (2006) and McGrath (2005) used a persistence design in which participants could stop the slot machine session at any point, whereas Limbrick-Oldfield et al., (2021) used a variation on this design where there was a fixed period of slot machine play (10 mins in Experiment 1, 5 mins in Experiment 2) followed by a persistence phase. Brandt \& Martin (2015) used a procedure in which the first 2 trials in each block required the participant to "work" for their endowment, by pressing a button repeatedly to earn points. For the remainder of each block, the participant could then choose between a slot machine bet (a risky choice) or continuing with the work task (a non-risky choice). The earning procedure itself was not manipulated in Brandt \& Martin (2015), i.e. all participants performed the earning trials (although see Limbrick-Oldfield et al., 2021 Experiment 2 for a manipulation of this factor).

In terms of the findings, two studies indicated reduced gambling tendencies under heightened monetary salience. In Weatherly et al (2006) Experiment 1, the group who held the $\$ 10$ endowment during the instruction stage played significantly fewer trials and bet fewer points, compared to a group who only saw the $\$ 10$ bill and a group who did not see or hold the cash. In Experiment 2, as the monetary value ('exchange rate') of the tokens increased, participants played significantly fewer trials. Thus, these findings are in line with Weatherly \& Brandt (2004), and Peterson \& Weatherly (2011) in the presence/absence of money category. In Brandt \& Martin (2015), emphasizing the monetary worth within the instructions did not affect preferences for the gambling vs work option, but the presence of the periodic balance reminder did significantly reduce decisions to gamble.

The other two papers yielded mixed results. Limbrick-Oldfield et al., (2021) Experiment 1 randomized participants to a cash condition (where they held $\$ 40$ and inserted it into the machine) or a 'voucher' condition (based on a casino ticket in/ticket out voucher). In Experiment 2, participants acquired their $\$ 40$ cash endowment through an earning procedure or as a simple endowment ('windfall'). On the aggregated session-level behavioural measures, there were no observed differences between conditions in either experiment. Although, in a secondary trial-level regression analysis, the speed of play and bet size were seen to vary as a function of other game features (e.g. losing streaks and win size), indicating that the basic laboratory design was behaviourally sensitive. In McGrath (2005), participants in one condition inserted their endowed coins into the slot machine, while in the other condition the credits were pre-loaded by the experimenter. The number of bets per minute and amount bet per minute were both lower in the condition where the participants handled their funds, in line with Weatherly et al. (2006), but another effect in the opposite direction was found for the overall amount bet.

\section{Testing 'Responsible Gambling' Tools}

This category comprises two field studies (Blaszczynski et al., 2005; Sharpe et al., 2005), and one laboratory study (Loba et al., 2001). In each case, modified EGMs were configured to different settings to test the effects of potential 'responsible gambling' tools. Samples were gambling venue patrons in Blaszczynski et al., (2005) and Sharpe et al., (2005), comprising a mixture of recreational gamblers and individuals with disordered gambling. Loba et al., (2001) recruited subgroups of community gamblers with and without pathological gambling. The two field studies were from the same research team, and used the same modified EGMs. The key difference between the studies was that in Blaszczynski et al., (2005), participants were assigned to play each EGM for 20 spins, in a randomized order, and then provided ratings on their experience. In Sharpe et al., (2005) the gambling behaviour (e.g., amount of money bet, session duration) was monitored while venue patrons used EGMs of their own choice, and thus this study was formally 'quasi experimental', since participants were not randomized to the 
different EGM conditions. Loba et al., (2001) used a post-game questionnaire to assess the effects of the different RG manipulations.

Notably, each of these three studies employed multiple conditions, where the monetary factor(s) was manipulated alongside other structural characteristics. In Blaszczynski et al., (2005) and Sharpe et al., (2005), 3 features were manipulated in a formal $2 \times 2 \times 2$ design: the length of the reel spin (a nonmonetary factor), the maximum bill denomination (either $\$ 20$ or $\$ 100$; we consider this to be a monetary manipulation), or the maximum bet limit on a single spin ( $\$ 1$ vs $\$ 10$; we consider this to be a monetary manipulation). Across both studies, there was no effect of the bill denomination factor on either self-report ratings (e.g., satisfaction and enjoyment) or the gambling behavioural measures. Limiting the maximum bet to $\$ 1$ did not significantly affect self-report ratings (Blaszczynski et al., 2005), but in Sharpe et al., (2005), the $\$ 10$ maximum bet was associated with longer sessions, higher bets, and greater sustained losses than the $\$ 1$ max bet. Blaszczynski et al., (2005) tested for differential effects of the RG modifications in participants with pathological gambling, and saw overall reductions in enjoyment and satisfaction compared to recreational gamblers, but group status did not interact with the specific RG tools (Blaszczynski et al., 2005).

The laboratory study by Loba et al., (2001) included a manipulation of an on-screen counter that kept track of the total amount of money wagered (we consider this to be a monetary manipulation), as well as other manipulations of speed of play, auditory sensory feedback, and a 'stopper' button condition, which are non-monetary factors. We note that the design in Loba et al., (2001) was not fully factorial, but one sub-analysis involved random assignment to counter-on or counter-off conditions. The counteron groups reported significantly greater 'tension'. A further interaction effect was observed with pathological gambling group status on the 'ease of stopping' rating, where the group with pathological gambling reported that it was easier to stop playing in the counter-on condition (Loba et al., 2001).

\section{Monetary inducements}

Two recent studies employed manipulations of 'promotional inducements' (Challet-Bouju et al., 2020; Kim et al., 2021). In Challet-Bouju et al. (2020), online gamblers played a session of online gambling at a laboratory, using their own funds. Participants were randomized to receive varying windfall sums ( $€ 10$, $€ 50, € 100, € 200$, or a control condition) at a midpoint of their session, designed to simulate a promotional inducement (Challet-Bouju et al., 2020). The windfalls did not capture some of the terms and conditions of authentic promotions. Half of the participants scored at-risk for problem gambling. The four inducement conditions were compared to the control condition on several dependent measures, including gambling behaviour (e.g. total money wagered, time spent gambling) and subjective measures, and this is the only study that we identified measuring effects on gambling-related cognitions (using the GRCS). Participants in the $€ 100$ and $€ 200$ inducement groups wagered significantly more than the control condition. There were no differences across conditions on time spent gambling. There was an increase in the GRCS Gambling Expectancies subscale following the gambling session in the $€ 10$ and $€ 50$ groups, although it is notable that this effect was only observed for the lower inducement amounts. Those with at-risk levels of gambling played significantly longer sessions and wagered significantly more money, but there was no interaction effect between at-risk gambling status and inducement condition. 
The study by Kim et al. (2021) used an unusual design based on a free play "social casino" slot machine game, on which participants could earn funds to gamble on a subsequent roulette game. Participants received credits to play the free game each day for a week, and received $\$ 1$ every day that they played. Participants were randomized to two groups. In one group, participants could earn a further real-money bonus (\$1-\$5) based on their remaining credits after 7 days. No such bonus was available for the other group. Participants in the reward condition placed higher bets in the free game, but there were no between-group differences in real-money gambling behaviour on the subsequent roulette task.

\section{Discussion}

This scoping review identified controlled experimental studies testing the effects of monetary manipulations on gambling behaviour, in order to better inform ongoing regulatory discussions about the impact of digital payment methods and cashless technologies on gambling. Eligibility criteria required studies to characterize participants using a standardized measure of gambling involvement (e.g. PGSI) and use either an authentic or simulated gambling procedure for the monetary manipulation. One important take-away is the small number of primary studies that were identified: only 19 publications, reporting 23 individual experiments. These studies could be organized in four categories, based on four major kinds of monetary manipulation. The most common design, in 12 of 23 experiments, compared gambling under the presence or absence of monetary reward. Smaller numbers of experiments were identified manipulating monetary salience, testing RG tools, and testing the impact of promotional inducements. In general, these studies employed a range of outcome measures (subjective, behavioural, and physiological), as well as a range of samples that included varying levels of gambling involvement and pathology. Only a few studies formally tested for differences between groups with disordered versus non-disordered gambling (c.f. Loba et al., 2001; Challet-Bouju et al., 2020, McGrath, 2006).

Controlled experiments are considered the definitive design for testing the causal effect of a variable (Mill, 2011). For determining whether cashless payment options increase gambling-related harms, an ideal design would compare gambling using cash against such alternative payment forms. We found two studies fitting this description, which used authentic slot machines to compare gambling with cash against a second condition where the participants either used a voucher (Limbrick-Oldfield et al, 2021 Expt 1), or the credits were 'pre-loaded' into the slot machine by the research team (McGrath, 2005). We found no studies testing contemporary options such as banking cards or other digital payment options in the context of gambling behaviour (c.f. Banker et al., 2021; Ceravolo et al., 2019)). Filling this knowledge gap will be critical to inform ongoing decisions in many jurisdictions (e.g., Gainsbury \& Blaszczynski, 2020; GREO et al., 2020). The modal group of studies comparing the presence versus absence of money are reasonably dated (from 1995 to 2011), and although these studies have been influential in guiding gambling theory around monetary reinforcement and arousal (Sharpe et al., 1995 ; Binde, 2013), these studies do not clearly speak to the contemporary issues around 'cashless gambling'. With a digital technology, gambling still entails the use of money, only in formats in which the attrition of one's funds may be less visible and/or "painful". The category of manipulations that is most relevant to this debate are those manipulating monetary salience (Weatherly et al., 2006; Brandt \& Martin, 2015; McGrath, 2005; Limbrick-Oldfield et al., 2021), in which all conditions gamble for equivalent monetary incentives, but the psychological representation of the funds is manipulated. Within this category, a number of studies using student participants found that with increasing monetary salience, behavioural measures of gambling intensity were reduced - findings that are broadly in line with the 'pain of paying' 
hypothesis (Prelec \& Loewenstein, 1998). The effects were less consistent in community samples with gambling experience, with one study reporting no effects on the primary measures (Limbrick-Oldfield et al., 2021) and another study reporting some effects in both directions (McGrath, 2005). Further research is required testing these effects in people with at-risk and problematic levels of gambling, but the specific manipulations that are outlined in this section may provide a template for this future work.

Our third category, of monetary manipulations within RG tools, may be considered within a wider body of work evaluating gambling harm reduction tools 'in the field' using controlled designs (see also Heirene \& Gainsbury, 2021 ; Ivanova et al., 2019; Jonsson et al., 2020). The 3 specific manipulations subsumed in this category were each quite different. The counter manipulation in Loba et al., (2001) could be considered a salience manipulation, although it is primarily the financial display that is being manipulated. In line with the effect of the counter on 'ease of stopping' ratings among people with gambling problems, an observational study by Ladouceur \& Sevigny (2009) found that gamblers regarded a cash display (on Video Lottery Terminals) as being 'more helpful' compared to a credits display, while no effects were observed for an in-game clock or a pre-commitment device to limit the session length. Limiting the bill denominations in Blaszczynski et al. (2005) and Sharpe et al. (2005) had limited efficacy. Although limits on bill acceptors can be easily implemented as a harm reduction tool, we regard this as a subtle manipulation, as a gambler can still deposit the same funds, e.g. using five \$20 bills instead of a $\$ 100$. The second manipulation, of the maximum bet size, in these two experiments is rather more interesting, and pertains to a regulatory debate around 'high-stakes' EGMs (Forrest et al., 2015; Parke \& Parke, 2013) that is somewhat distinct from the issue of cashless gambling.

The recent study by Challet-Bouju et al. (2020) exemplifies a new theme looking at effects of promotional funds, a form of gambling marketing that is common in the online environment and in relation to sports and race wagering. The experiment by Challet-Bouju et al. (2020) randomized online gamblers to receive one of four levels of complementary funds during their session. A similar field study by Rüdisser et al. (2017) randomized participants to receive a free-play coupon (valued between 5 and 50 Swiss Francs) at the entrance to the casino. In contrast to the findings by Challet-Bouju et al. (2020), the tracked behaviour in the Rudisser et al. (2017) study showed a 15-30\% reduction in betting in the inducement condition (a 'reverse house money effect'). As Rudisser et al. (2017) did not include any screening tool for gambling involvement, this study was ineligible for our analysis. Another recent study hypothesized that bonus payments from a free-to-play social casino game (akin to an inducement) would increase subsequent gambling on a real-money game, but the hypothesis was not supported (Kim et al., 2021). Nevertheless, a study using ecological momentary assessment (as a non-experimental technique) over a 3-week period in sports and race bettors found significant effects of a range of specific inducement forms on betting expenditure (Browne et al., 2019), and further studies are clearly warranted to elaborate on this emerging form at the intersection between payment technologies and marketing.

We note some limitations with the current review. The protocol was not pre-registered. Although we attempted to search the grey literature via the GREO library and a social media post for unpublished work, the only non-journal publications identified were two unpublished theses. While other databases exist for accessing grey literature, best practices for searching the grey literature on gambling are currently lacking. Lastly, our organizational structure of the four categories is a heuristic; some heterogeneity exists within each category (for example among the different salience manipulations), and there are also links between categories, as noted above. We are cognisant that clean boundaries do 
not necessarily exist between monetary manipulations and some other structural characteristics of gambling products (e.g. jackpot sizes), and other Responsible Gambling effects such as unprompted limit setting (Ivanova et al, 2019) or expenditure pop-ups (Byrne \& Russell, 2020).

Overall, our scoping review highlights a paucity of research on the effects of monetary manipulations on gambling, using controlled experimental designs that permit causal conclusions to be drawn (Mill, 2011). This likely reflects a range of methodological and ethical issues. Although experimental designs are a 'gold standard', they may be neither practical nor effective. Laboratory studies readily allow randomization of participants to different conditions, but such studies have mostly relied on endowed funds for gambling. It is possible that any 'pain of paying' style effects may be attenuated with endowed funds (i.e. when using money that did not belong to the participant prior to the experiment) (see Limbrick-Oldfield et al., 2021 for further discussion). Similar dilemmas arise in behavioural economics, where 'real effort' procedures (Erkal et al., 2011) have been devised for the lab to enhance ecological validity in relation to monetary factors. Ethical considerations also exist in relation to both the use of participants' own funds (Cantinotti et al., 2016) and testing for monetary effects in people with gambling problems. Some of these issues can be overcome in research using field data, such as online gambling datasets or card-based casino tracking (Rudisser et al. 2017), where the gamblers are inherently using their own funds. Controlled experimental designs may be challenging to run in naturalistic settings, although recent studies are raising the bar in the use of such designs for testing other Responsible Gambling features (e.g. Heirene \& Gainsbury, 2021). Nevertheless, constraints exist 'in the field' as well as in the laboratory - for example, it is impossible for online gamblers to bet with cash. Ultimately, progress in this area is likely to require convergent data from both field studies and more tightlycontrolled laboratory research. The studies identified by this scoping review highlight a range of experimental interventions and procedural nuances that can help guide future work, in order to inform ongoing policy discussions regarding the possible impact of cashless technologies on gambling-related harms. 


\section{References}

Abarbanel, B. (2018). Gambling vs gaming: A commentary on the role of regulatroy, industry, and community stakeholders in the loot box depbate. Gaming Law Review, 22(4), 231-234. https://doi.org/10.1089/glr2.2018.2243

Arksey, H., \& O'Malley, L. (2005). Scoping studies: Towards a methodological framework. International Journal of Social Research Methodology, 8(1), 19-32. https://doi.org/10.1080/1364557032000119616

Banker, S., Dunfield, D., Huang, A., \& Prelec, D. (2021). Neural mechanisms of credit card spending. Scientific Reports, 11(1), 4070. https://doi.org/10.1038/s41598-021-83488-3

Binde, P. (2013). Why people gamble: A model with five motivational dimensions. International Gambling Studies, 13(1), 81-97. https://doi.org/10.1080/14459795.2012.712150

Blaszczynski, A., Sharpe, L., Walker, M., Shannon, K., \& Coughlan, M.-J. (2005). Structural characteristics of electronic gaming machines and satisfaction of play among recreational and problem gamblers. International Gambling Studies, 5(2), 187-198. https://doi.org/10.1080/14459790500303378

Brandt, A. E., \& Martin, J. (2015). Simulating personal wealth in the laboratory. The Journal of General Psychology, 142(3), 167-181. https://doi.org/10.1080/00221309.2015.1060937

Browne, M., Hing, N., Russell, A. M. T., Thomas, A., \& Jenkinson, R. (2019). The impact of exposure to wagering advertisements and inducements on intended and actual betting expenditure: An ecological momentary assessment study. Journal of Behavioral Addictions, 8(1), 146-156.

https://doi.org/10.1556/2006.8.2019.10

Byrne, C. A., \& Russell, A. M. T. (2020). Making EGMs accountable: Can an informative and dynamic interface help players self-regulate? Journal of Gambling Studies, 36(4), 1229-1251.

https://doi.org/10.1007/s10899-019-09889-2

Cantinotti, M., Leclerc, B.-S., Brochu, P., Jacques, C., Sévigny, S., \& Giroux, I. (2016). The effect of research compensation in the form of cheques on gamblers cash-in behaviour. Journal of Gambling Issues, 32, 1-10. https://doi.org/10.4309/jgi.2016.32.1

Ceravolo, M. G., Fabri, M., Fattobene, L., Polonara, G., \& Raggetti, G. (2019). Cash, card or smartphone: The neural correlates of payment methods. Frontiers in Neuroscience, 13, 1188.

https://doi.org/10.3389/fnins.2019.01188

Challet-Bouju, G., Grall-Bronnec, M., Saillard, A., Leboucher, J., Donnio, Y., Péré, M., \& Caillon, J. (2020). Impact of wagering inducements on the gambling behaviors, cognitions, and emotions of online gamblers: A randomized controlled study. Frontiers in Psychiatry, 11.

https://doi.org/10.3389/fpsyt.2020.593789

Erkal, N., Gangadharan, L., \& Nikiforakis, N. (2011). Relative earnings and giving in a real-effort experiment. American Economic Review, 101(7), 3330-3348. https://doi.org/10.1257/aer.101.7.3330

Forrest, D., McHale, I. G., \& Wardle, H. (n.d.). Evaluating the impact of the uplift of stakes and prizes on B1 gaming machines in casinos. 66. 
Gainsbury, S. M., Angus, D. J., \& Blaszczynski, A. (2019). Isolating the impact of specific gambling activities and modes on problem gambling and psychological distress in internet gamblers. BMC Public Health, 19(1), 1372. https://doi.org/10.1186/s12889-019-7738-5

Gainsbury, S. M., \& Blaszczynski, A. (2020). Digital gambling payment methods: Harm minimization policy considerations. Gaming Law Review, 24(7), 466-472. https://doi.org/10.1089/glr2.2020.0015

GREO, Sztainert, T., Baxter, D., McKnight, S., \& Voll, J. (2020). The role of credit cards in gambling. Gambling Research Exchange (GREO). https://doi.org/10.33684/2020.001

Griffiths, M. (1993). Fruit machine gambling: The importance of structural characteristics. Journal of Gambling Studies, 9(2), 101-120. https://doi.org/10.1007/BF01014863

Haeusler, J. (2016). Follow the money: Using payment behaviour as predictor for future self-exclusion. International Gambling Studies, 16(2), 246-262. https://doi.org/10.1080/14459795.2016.1158306

Heirene, R. M., \& Gainsbury, S. M. (n.d.). Encouraging and evaluating limit-setting among on-line gamblers: A naturalistic randomized controlled trial. Addiction, $n / a(\mathrm{n} / \mathrm{a})$.

https://doi.org/10.1111/add.15471

Hollander, E., Pallanti, S., Baldini Rossi, N., Sood, E., Baker, B. R., \& Buchsbaum, M. S. (2005). Imaging monetary reward in pathological gamblers. The World Journal of Biological Psychiatry: The Official Journal of the World Federation of Societies of Biological Psychiatry, 6(2), 113-120. https://doi.org/10.1080/15622970510029768

Ivanova, E., Magnusson, K., \& Carlbring, P. (2019). Deposit limit prompt in online gambling for reducing gambling intensity: A randomized controlled trial. Frontiers in Psychology, 10.

https://doi.org/10.3389/fpsyg.2019.00639

Jonsson, J., Hodgins, D. C., Munck, I., \& Carlbring, P. (2020). Reaching out to big losers leads to sustained reductions in gambling over 1 year: A randomized controlled trial of brief motivational contact.

Addiction, 115(8), 1522-1531. https://doi.org/10.1111/add.14982

Kim, H. S., Rockloff, M., Leslie, D., McGrath, D. S., Wohl, M. J. A., \& Hodgins, D. C. (2021). Offering small tangible rewards within social casino games increases in-play bets but does not impact real-money gambling. Addictive Behaviors, 120, 106984. https://doi.org/10.1016/j.addbeh.2021.106984

Krmpotich, T. D. (2016). Slot machine use as a measure of decision-making in substance use disorders [M.A., The University of North Dakota]. In ProQuest Dissertations and Theses (1796968866). ProQuest Dissertations \& Theses Global. https://www.proquest.com/dissertations-theses/slot-machine-use-asmeasure-decision-making/docview/1796968866/se-2 ?accountid=14656

Krueger, T. H. C., Schedlowski, M., \& Meyer, G. (2005). Cortisol and heart rate measures during casino gambling in relation to impulsivity. Neuropsychobiology, 52(4), 206-211.

https://doi.org/10.1159/000089004

Ladouceur, R., \& Sévigny, S. (2009). Electronic gambling machines: Influence of a clock, a cash display, and a precommitment on gambling time. Journal of Gambling Issues, O(23), 31-41.

https://doi.org/10.4309/jgi.2009.23.2 
Ladouceur, R., Sévigny, S., Blaszczynski, A., O’Connor, K., \& Lavoie, M. E. (2003). Video lottery: Winning expectancies and arousal. Addiction (Abingdon, England), 98(6), 733-738.

https://doi.org/10.1046/j.1360-0443.2003.00412.x

Lapuz, J., \& Griffiths, M. D. (2010). The role of chips in poker gambling: An empirical pilot study. Gambling Research: Journal of the National Association for Gambling Studies (Australia). https://search.informit.org/doi/abs/10.3316/informit.223149445402224

Lesieur, H. R., \& Blume, S. B. (1987). The South Oaks Gambling Screen (SOGS): A new instrument for the identification of pathological gamblers. The American Journal of Psychiatry, 144(9), 1184-1188. https://doi.org/10.1176/ajp.144.9.1184

Limbrick-Oldfield, E. H., Chua, C., Cringle, N., MacDonald, K., Ferrari, M. A., Zhang, K., \& Clark, L. (2021). Cashless gambling and the pain of paying: Effects of monetary format on slot machine gambling. Addiction Research \& Theory. https://doi.org/10.1080/16066359.2021.2009465

Loba, P., Stewart, S. H., Klein, R. M., \& Blackburn, J. R. (2001). Manipulations of the features of standard video lottery terminal (VLT) games: Effects in pathological and non-pathological gamblers. Journal of Gambling Studies, 17(4), 297-320. https://doi.org/10.1023/a:1013639729908

McGrath, D. (2005). A comparison of an e-ticket simulation and coin slot machines: Effects in problem and non-problem gamblers [M.Sc., University of Guelph (Canada)]. In ProQuest Dissertations and Theses (305335228). ABI/INFORM Collection; ProQuest Dissertations \& Theses Global.

https://www.proquest.com/dissertations-theses/comparison-e-ticket-simulation-coin-slotmachines/docview/305335228/se-2?accountid=14656

Meyer, G., Fiebig, M., Häfeli, J., \& Mörsen, C. (2011). Development of an assessment tool to evaluate the risk potential of different gambling types. International Gambling Studies, 11(2), 221-236.

https://doi.org/10.1080/14459795.2011.584890

Meyer, G., Hauffa, B. P., Schedlowski, M., Pawlak, C., Stadler, M. A., \& Exton, M. S. (2000). Casino gambling increases heart rate and salivary cortisol in regular gamblers. Biological Psychiatry, 48(9), 948953. https://doi.org/10.1016/s0006-3223(00)00888-x

Mill, J. S. (2011). A system of logic, ratiocinative and inductive: Being a connected view of the principles of evidence, and the methods of scientific investigation. (Vol. 1). Cambridge University Press. https://doi.org/10.1017/CBO9781139149839

Munn, Z., Peters, M. D. J., Stern, C., Tufanaru, C., McArthur, A., \& Aromataris, E. (2018). Systematic review or scoping review? Guidance for authors when choosing between a systematic or scoping review approach. BMC Medical Research Methodology, 18(1), 143. https://doi.org/10.1186/s12874-018-0611-x

Newall, P. W. S., Russell, A. M. T., \& Hing, N. (2021). Structural characteristics of fixed-odds sports betting products. Journal of Behavioral Addictions. https://doi.org/10.1556/2006.2021.00008

Page, M. J., McKenzie, J. E., Bossuyt, P. M., Boutron, I., Hoffmann, T. C., Mulrow, C. D., Shamseer, L., Tetzlaff, J. M., Akl, E. A., Brennan, S. E., Chou, R., Glanville, J., Grimshaw, J. M., Hróbjartsson, A., Lalu, M. M., Li, T., Loder, E. W., Mayo-Wilson, E., McDonald, S., ... Moher, D. (2021). The PRISMA 2020 statement: An updated guideline for reporting systematic reviews. BMJ, 372, n71. https://doi.org/10.1136/bmj.n71 
Parke, J., \& Griffiths, M. (2006). The psychology of the fruit machine: The role of structural characteristics (revisited). International Journal of Mental Health and Addiction, 4(2), 151-179. https://doi.org/10.1007/s11469-006-9014-z

Parke, J., \& Parke, A. (2013). Does size really matter?A review of the role of stake and prize levels in relation to gambling-related harm. The Journal of Gambling Business and Economics, 7(3), 77-110. https://doi.org/10.5750/jgbe.v7i3.819

Parke, J., Rigbye, J., \& Parke, A. (2008, December). Cashless and card-based technologies in gambling: A review of the literature [Monograph]. Gambling Commission.

http://www.gamblingcommission.gov.uk/research_consultations/research/research_programme/cashl ess_card-based_techno.aspx

Peterson, J., \& Weatherly, J. (2011). Comparing three strategies of motivating gambling behavior in the laboratory environment. Analysis of Gambling Behavior, 5(1).

https://repository.stcloudstate.edu/agb/vol5/iss1/4

Pettit, N. C., \& Sivanathan, N. (2011). The plastic trap: Self-threat drives credit usage and status consumption. Social Psychological and Personality Science, 2(2), 146-153.

https://doi.org/10.1177/1948550610385138

Prelec, D., \& Loewenstein, G. (1998). The red and the black: Mental accounting of savings and debt. Marketing Science, 17(1), 4-28. https://doi.org/10.1287/mksc.17.1.4

Prelec, D., \& Simester, D. (n.d.). Always leave home without it: A further investigation of the credit-card effect on willingness to pay. 8.

Reber, A. (2012). The EVF model: A novel framework for understanding gambling and, by extension, poker. UNLV Gaming Research \& Review Journal, 16(1).

https://digitalscholarship.unlv.edu/grrj/vol16/iss1/4

Roby, K. J., \& Lumley, M. A. (1995). Effects of accuracy feedback versus monetary contingency on arousal in high and low frequency gamblers. Journal of Gambling Studies, 11(2), 185-193.

https://doi.org/10.1007/BF02107114

Rodda, S. N., Bagot, K. L., Cheetham, A., Hodgins, D. C., Hing, N., \& Lubman, D. I. (2018). Types of change strategies for limiting or reducing gambling behaviors and their perceived helpfulness: A factor analysis. Psychology of Addictive Behaviors, 32(6), 679-688. https://doi.org/10.1037/adb0000393

Rüdisser, M., Flepp, R., \& Franck, E. (2017). Do casinos pay their customers to become risk-averse? Revising the house money effect in a field experiment. Experimental Economics, 20(3), 736-754. https://doi.org/10.1007/s10683-016-9509-9

Sharpe, L., Tarrier, N., Schotte, D., \& Spence, S. H. (1995). The role of autonomic arousal in problem gambling. Addiction, 90(11), 1529-1540. https://doi.org/10.1046/j.1360-0443.1995.9011152911.x

Sharpe, L., Walker, M., Coughlan, M.-J., Enersen, K., \& Blaszczynski, A. (2005). Structural changes to electronic gaming machines as effective harm minimization strategies for non-problem and problem gamblers. Journal of Gambling Studies, 21(4), 503-520. https://doi.org/10.1007/s10899-005-5560-8 
Soman, D. (2003). The effect of payment transparency on consumption: Quasi-experiments from the field. Marketing Letters, 14(3), 11.

Stewart, M. J., \& Wohl, M. J. A. (2013). Pop-up messages, dissociation, and craving: How monetary limit reminders facilitate adherence in a session of slot machine gambling. Psychology of Addictive Behaviors: Journal of the Society of Psychologists in Addictive Behaviors, 27(1), 268-273.

https://doi.org/10.1037/a0029882

Swanton, T. B., Gainsbury, S. M., \& Blaszczynski, A. (2019). The role of financial institutions in gambling. International Gambling Studies, 19(3), 377-398. https://doi.org/10.1080/14459795.2019.1575450

Thomas, M., Desai, K. K., \& Seenivasan, S. (2011). How credit card payments increase unhealthy food purchases: Visceral regulation of vices. Journal of Consumer Research, 38(1), 126-139.

https://doi.org/10.1086/657331

Tricco, A. C., Lillie, E., Zarin, W., O’Brien, K. K., Colquhoun, H., Levac, D., Moher, D., Peters, M. D. J., Horsley, T., Weeks, L., Hempel, S., Akl, E. A., Chang, C., McGowan, J., Stewart, L., Hartling, L., Aldcroft, A., Wilson, M. G., Garritty, C., ... Straus, S. E. (2018). PRISMA extension for scoping reviews (PRISMA-ScR): Checklist and explanation. Annals of Internal Medicine, 169(7), 467-473. https://doi.org/10.7326/M180850

Weatherly, J., \& Brandt, A. (2004). Participants' sensitivity to percentage payback and credit value when playing a slot-machine simulation. Behavior and Social Issues, 13, 33-50.

https://doi.org/10.5210/bsi.v13i1.34

Weatherly, J., McDougall, C. L., \& Gillis, A. A. (2006). A bird in hand: Discouraging gambling on a slot machine simulation. The Journal of Psychology, 140(4), 347-361.

https://doi.org/10.3200/JRLP.140.4.347-361

Wulfert, E., Franco, C., Williams, K., Roland, B., \& Maxson, J. H. (2008). The role of money in the excitement of gambling. Psychology of Addictive Behaviors: Journal of the Society of Psychologists in Addictive Behaviors, 22(3), 380-390. https://doi.org/10.1037/0893-164X.22.3.380

Wulfert, E., Roland, B., Hartley, J., Wang, N., \& Franco, C. (2005). Heart rate arousal and excitement in gambling: Winners versus losers. Psychology of Addictive Behaviors : Journal of the Society of Psychologists in Addictive Behaviors, 19, 311-316. https://doi.org/10.1037/0893-164X.19.3.311 
Table 1: Definitions

\begin{tabular}{|l|l|}
\hline $\begin{array}{l}\text { Payment vs monetary } \\
\text { format }\end{array}$ & $\begin{array}{l}\text { We use 'monetary format' as a broad umbrella term, and we distinguish } \\
\text { how the wager is paid ('payment') from how gambling wins are returned to } \\
\text { the gambler ('payout'). Payment and payout need not take the same } \\
\text { format; for example a gambler may insert a \$20 bill to play a slot machine, } \\
\text { but receive their winnings as a TITO voucher that can be inserted into } \\
\text { another slot machine or redeemed as cash at a cashier's booth. }\end{array}$ \\
\hline Digital vs cashless & $\begin{array}{l}\text { Intuitively, 'cashless' formats refers to any non-cash medium. This could } \\
\text { include converting cash into in-venue chips, or a TITO voucher. Digital } \\
\text { transactions are made between a consumer and gambling provider directly } \\
\text { via a bank account or e-wallet, without the use of physical cash as an } \\
\text { intermediary. }\end{array}$ \\
\hline Debit vs credit cards & $\begin{array}{l}\text { Debit transactions occur instantaneously to or from the bank account. } \\
\text { Credit card transactions utilize credit from a financial institution that is } \\
\text { repaid with incurred interest, typically through monthly statements. } \\
\text { Gambling transactions on a credit card may be processed as cash } \\
\text { withdrawals, which can incur higher interest rates (Swanton et al., 2019). }\end{array}$ \\
\hline $\begin{array}{l}\text { Endowments, } \\
\text { promotional funds and } \\
\text { inducements }\end{array}$ & $\begin{array}{l}\text { In the context of this article, because the term 'credit' is also used to refer } \\
\text { to credit cards, we use the term 'points' to refer to any non-monetary } \\
\text { conditions, which may be called gambling with credits, tokens, or points. } \\
\text { endowment) to play the gambling game. Participants often receive some } \\
\text { form of real-money bonus based on remaining funds at the end of the } \\
\text { session. In real gambling situations, gamblers may also receive promotional } \\
\text { funds or inducements as a form of marketing, e.g. a \$10 voucher in return } \\
\text { for making a deposit with an online gambling operator. }\end{array}$ \\
\hline
\end{tabular}


Table 2. Included Studies

\begin{tabular}{|c|c|c|c|c|c|}
\hline Citation & Sample & $\begin{array}{l}\text { Gambling } \\
\text { Instrument }\end{array}$ & $\begin{array}{l}\text { Gambling Task and } \\
\text { Dependent Variables }\end{array}$ & Monetary Manipulation & Results \\
\hline \multicolumn{6}{|c|}{ Real vs Hypothetical } \\
\hline $\begin{array}{l}\text { Roby \& } \\
\text { Lumley (1995) }\end{array}$ & $\mathrm{N}=70$ students & SOGS & $\begin{array}{l}\text { Gambling device } \\
\text { resembled a slot } \\
\text { machine with a row of } \\
\text { five lights. The } \\
\text { participant's task was to } \\
\text { guess which upper light } \\
\text { would be illuminated on } \\
\text { each trial. Physiological } \\
\text { measures were heart } \\
\text { rate, skin conductance, } \\
\text { and skin temperature. } \\
\text { Self-report measures } \\
\text { were subjective arousal } \\
\text { and pleasure. }\end{array}$ & $\begin{array}{l}\text { Within-subjects design } \\
\text { involving two sessions: } \\
\text { playing blackjack for money, } \\
\text { and blackjack for points. }\end{array}$ & $\begin{array}{l}\text { In comparing the money and } \\
\text { feedback-only conditions, } \\
\text { significant differences were } \\
\text { seen on all measures. High } \\
\text { SOGS group experienced } \\
\text { larger decreases in skin } \\
\text { temperature and subjective } \\
\text { pleasure. }\end{array}$ \\
\hline $\begin{array}{l}\text { Meyer et al } \\
(2000)\end{array}$ & $\begin{array}{l}\mathrm{N}=10 \text { casino } \\
\text { blackjack } \\
\text { gamblers }\end{array}$ & $\begin{array}{l}\text { German } \\
\text { gambling } \\
\text { diagnostic } \\
\text { (Petry, } \\
\text { 1996) }\end{array}$ & $\begin{array}{l}\text { The gambling task was } \\
\text { blackjack. Heart rate } \\
\text { was monitored } \\
\text { throughout, and saliva } \\
\text { samples were taken to } \\
\text { assay cortisol. }\end{array}$ & $\begin{array}{l}\text { Within-subjects design } \\
\text { involving two sessions: } \\
\text { playing blackjack for real } \\
\text { money, and blackjack for } \\
\text { points. Both sessions were } \\
\text { completed in the casino } \\
\text { environment. Participants } \\
\text { used their own money in the } \\
\text { experimental condition. }\end{array}$ & $\begin{array}{l}\text { Gambling for money was } \\
\text { associated with a } \\
\text { significantly higher heart } \\
\text { rate and cortisol levels. }\end{array}$ \\
\hline $\begin{array}{l}\text { Ladouceur et } \\
\text { al (2003) }\end{array}$ & $\begin{array}{l}\mathrm{N}=34 \\
\text { community } \\
\text { gamblers }\end{array}$ & SOGS & $\begin{array}{l}\text { Authentic slot machine } \\
\text { gambling, with } \\
\text { monitoring of heart } \\
\text { rate, and self-reported } \\
\text { arousal. }\end{array}$ & $\begin{array}{l}\text { Between-groups design: all } \\
\text { participants were initially } \\
\text { familiarized with the slot } \\
\text { machine for } 50 \text { spins, and } \\
\text { then randomized to either } \\
\text { monetary reward (who could }\end{array}$ & $\begin{array}{l}\text { Gambling for money was } \\
\text { associated with significantly } \\
\text { higher heart rate. } \\
\text { Participants in the monetary } \\
\text { group reported feeling more }\end{array}$ \\
\hline
\end{tabular}




\begin{tabular}{|c|c|c|c|c|c|}
\hline & & & & $\begin{array}{l}\text { win an additional } \$ 40 \text { ) or } \\
\text { points reward (who could } \\
\text { not win any money). }\end{array}$ & $\begin{array}{l}\text { excited during the second } \\
\text { phase. In the points group, } \\
\text { participants reported either } \\
\text { minor or no excitement. }\end{array}$ \\
\hline $\begin{array}{l}\text { Weatherly \& } \\
\text { Brandt (2004) }\end{array}$ & $\begin{array}{l}\text { Expt 1: } \mathrm{N}=63 \\
\text { students } \\
\text { Expt 2: } \mathrm{N}=8 \\
\text { students }\end{array}$ & SOGS & $\begin{array}{l}\text { Slot machine } \\
\text { simulation, deriving } \\
\text { behavioural measures: } \\
\text { number of trials played, } \\
\text { total points bet, and } \\
\text { total points remaining } \\
\text { at end. }\end{array}$ & $\begin{array}{l}\text { Experiment } 1 \text { was a } \\
\text { between-groups design with } \\
\text { a } 3 \text { (payback percentages: } \\
75 \%, 83 \% \text { and } 95 \% \text {, non- } \\
\text { monetary) x } 3 \text { (credit values: } \\
\$ 0, \$ 0.01 \text {, and } \$ 0.10 \text {, } \\
\text { monetary) factorial design. } \\
\text { Subjects were given a 100- } \\
\text { credit endowment, and in } \\
\text { the \$0.01 or \$0.10 } \\
\text { conditions, they were able to } \\
\text { win and keep any earnings. } \\
\text { Participants could quit the } \\
\text { session at any time up to } 15 \\
\text { mins. } \\
\text { Experiment } 2 \text { used the same } \\
\text { procedure, using a } 9 \text { session } \\
\text { within-subjects design. }\end{array}$ & $\begin{array}{l}\text { In both experiments, as } \\
\text { monetary reward value } \\
\text { increased, participants } \\
\text { played fewer trials ( } 0.01 \$ \\
\text { and } 0.10 \$ \text { vs } \$ 0 \text { condition), } \\
\text { placed lower bets ( } 0.01 \$ \\
\text { and } 0.10 \$ \text { vs } \$ 0 \text { condition), } \\
\text { and had more credits left at } \\
\text { the end of the session } \\
\text { (0.01\$ vs } \$ 0 \text { condition; } \$ 0.10 \\
\text { contrast not significant). } \\
\text { There was no significant } \\
\text { difference in the number of } \\
\text { points left between } \\
\text { participants in the } \$ 0.01 \text { and } \\
\$ 0.10 \text { conditions. }\end{array}$ \\
\hline $\begin{array}{l}\text { Krueger et al } \\
(2005)\end{array}$ & $\begin{array}{l}\mathrm{N}=29 \text { male } \\
\text { blackjack } \\
\text { gamblers, incl. } \\
9 \text { with } \\
\text { pathological } \\
\text { gambling }\end{array}$ & SOGS & $\begin{array}{l}\text { Gambling task was } \\
\text { blackjack. Physiological } \\
\text { DVs were heart rate and } \\
\text { cortisol levels (in } \\
\text { plasma) monitored } \\
\text { throughout session. }\end{array}$ & $\begin{array}{l}\text { Within-subjects design } \\
\text { involving two 90-minute } \\
\text { sessions of blackjack: one } \\
\text { with their own money in a } \\
\text { casino environment } \\
\text { (minimum stake of } 10 \text {-euro } \\
\text { max stake of } 500 \text { euro), one } \\
\text { without money in a lab. } \\
\text { Participant's degree of } \\
\text { impulsivity was also taken as } \\
\text { a predictor variable. }\end{array}$ & $\begin{array}{l}\text { Gambling for money was } \\
\text { associated with significantly } \\
\text { increased heart rate and } \\
\text { cortisol levels compared to } \\
\text { points condition. High } \\
\text { impulsivity was associated } \\
\text { with greater HR within the } \\
\text { money condition. }\end{array}$ \\
\hline
\end{tabular}




\begin{tabular}{|c|c|c|c|c|c|}
\hline $\begin{array}{l}\text { Wulfert et al } \\
(2005)\end{array}$ & $\begin{array}{l}\mathrm{N}=80 \\
\text { students (all } \\
\text { males) }\end{array}$ & SOGS & $\begin{array}{l}\text { Horse racing game, with } \\
\text { physiological } \\
\text { monitoring (heart rate) } \\
\text { and self-reported } \\
\text { arousal. }\end{array}$ & $\begin{array}{l}\text { Participants randomized to } 4 \\
\text { conditions, between-groups: } \\
2 \text { (wagering or not wagering) } \\
\times 2 \text { (winning or losing). This } \\
\text { generated } 4 \text { conditions: } \\
\text { picking a horse without } \\
\text { wagering, which would } \\
\text { either win (Condition } 1 \text { ) or } \\
\text { lose (Condition } 2 \text { ); wagering } \\
\$ 1 \text { on a horse that would } \\
\text { either win }(\$ 7 \text { prize) } \\
\text { (Condition } 3 \text { ) or lose } \\
\text { (Condition } 4 \text { ). }\end{array}$ & $\begin{array}{l}\text { During the race, monetary } \\
\text { wagers were associated with } \\
\text { significantly higher HR } \\
\text { increases and arousal than } \\
\text { non-monetary 'predictions'. } \\
\text { In the group who bet and } \\
\text { won, heart rate increases } \\
\text { were sustained in the } 30 \\
\text { seconds after the race, } \\
\text { compared to losers and non- } \\
\text { monetary predictions. }\end{array}$ \\
\hline $\begin{array}{l}\text { Hollander et al } \\
(2005)\end{array}$ & $\begin{array}{l}\mathrm{N}=7 \text { Ps with } \\
\text { pathological } \\
\text { gambling }\end{array}$ & SOGS & $\begin{array}{l}\text { Gambling task was } \\
\text { computerized blackjack. } \\
\text { Physiological DV was } \\
\text { brain activity in defined } \\
\text { regions of interest using } \\
\text { glucose PET. }\end{array}$ & $\begin{array}{l}\text { Within-subjects design } \\
\text { involving two blackjack } \\
\text { sessions performed during a } \\
\text { PET scan for glucose } \\
\text { metabolism, } 7 \text { days apart. } \\
\text { One scan used monetary } \\
\text { rewards, the other point } \\
\text { reward, with order } \\
\text { counterbalanced. }\end{array}$ & $\begin{array}{l}\text { Gambling for money was } \\
\text { associated with significant } \\
\text { increases in metabolism in } \\
\text { cingulate/medial frontal } \\
\text { cortex, dorsolateral } \\
\text { prefrontal cortex (R), } \\
\text { orbitofrontal cortex (L), and } \\
\text { ventral putamen. Gambling } \\
\text { severity was associated with } \\
\text { the difference in metabolic } \\
\text { rate between money and } \\
\text { points in cingulate cortex, } \\
\text { orbitofrontal cortex, and } \\
\text { visual cortex. }\end{array}$ \\
\hline $\begin{array}{l}\text { Wulfert et al } \\
(2008)\end{array}$ & $\begin{array}{l}\text { Expt 1: } \mathrm{N}= \\
243 \text { male } \\
\text { students } \\
\text { Expt 2: } \mathrm{N}= \\
200 \text { female } \\
\text { students }\end{array}$ & SOGS & $\begin{array}{l}\text { Horse racing game, with } \\
\text { physiological } \\
\text { monitoring (heart rate) } \\
\text { and self-reported } \\
\text { arousal. }\end{array}$ & $\begin{array}{l}\text { Between-groups design with } \\
4 \text { (expected payoff: \$0, } \$ 2, \\
\$ 7, \$ 15) \times 2 \text { (winning, losing) } \\
\text { conditions, and a further } \\
\text { baseline control group (who } \\
\text { watched the race without } \\
\text { predictions). }\end{array}$ & $\begin{array}{l}\text { Expt 1: Heart rate and } \\
\text { excitement increased in the } \\
\text { last } 30 \text { s of the race, in the } \\
\text { groups playing for larger } \\
\text { payoffs. In the period } \\
\text { following the race outcome } \\
\text { heart rate increased linearly }\end{array}$ \\
\hline
\end{tabular}




\begin{tabular}{|c|c|c|c|c|c|}
\hline & & & & & $\begin{array}{l}\text { with payoff size, and in } \\
\text { winners versus losers. In the } \\
\text { group who made non- } \\
\text { monetary predictions, } \\
\text { winning and losing races } \\
\text { were still associated with } \\
\text { significant HR increases. } \\
\text { In Study 2, results were } \\
\text { largely corroborated in a } \\
\text { sample of women, although } \\
\text { the precise function for } \\
\text { reward size was different: } \\
\text { females reported more } \\
\text { excitement for any wins } \\
\text { over } \$ 0, \text { whereas males } \\
\text { reported maximal } \\
\text { excitement for } \$ 15 \\
\text { maximum prize. }\end{array}$ \\
\hline $\begin{array}{l}\text { Peterson \& } \\
\text { Weatherly } \\
\text { (2011) }\end{array}$ & $\begin{array}{l}\mathrm{N}=13 \\
\text { students }\end{array}$ & SOGS & $\begin{array}{l}\text { Video poker task, } \\
\text { deriving several } \\
\text { measures of gambling } \\
\text { behaviour: number of } \\
\text { hands played } \\
\text { (persistence), number } \\
\text { of points bet (risk } \\
\text { taking), and number of } \\
\text { strategy errors. }\end{array}$ & $\begin{array}{l}\text { Within-subject design with } 3 \\
\text { payoff conditions over } \\
\text { separate video poker } \\
\text { sessions: } 1 \text { ) points reward, 2) } \\
\text { monetary reward (each } \\
\text { credit worth } \$ 0.05), 3) \text { the } \\
\text { participant with the most } \\
\text { credits win a } \$ 50 \text { gift card. }\end{array}$ & $\begin{array}{l}\text { Monetary reward condition } \\
\text { affected risk taking: } \\
\text { participants bet more points } \\
\text { in the points reward } \\
\text { condition compared to the } \\
\text { monetary reward condition } \\
\text { and the gift card condition, } \\
\text { which did not differ. } \\
\text { Monetary format did not } \\
\text { affect persistence or } \\
\text { strategy errors. }\end{array}$ \\
\hline $\begin{array}{l}\text { Krmpotich } \\
\text { (2016) }\end{array}$ & $\begin{array}{l}\mathrm{N}=40 \\
\text { students (17 } \\
\text { with } 2+ \\
\text { symptoms for }\end{array}$ & SOGS & $\begin{array}{l}\text { Authentic slot machine, } \\
\text { deriving behavioural } \\
\text { measures of total } \\
\text { number of trials played, } \\
\text { total number of tokens }\end{array}$ & $\begin{array}{l}\text { Mixed-factorial design with a } \\
\text { between-subjects factor } \\
\text { based on alcohol use ( } 2+\text { vs } \\
\text { no symptoms), and a within- } \\
\text { subjects monetary }\end{array}$ & $\begin{array}{l}\text { A marginally significant main } \\
\text { effect was found for } \\
\text { monetary reward condition } \\
\text { to reduce the amount bet } \\
\text { per trial, compared to the }\end{array}$ \\
\hline
\end{tabular}




\begin{tabular}{|c|c|c|c|c|c|}
\hline & $\begin{array}{l}\text { alcohol use } \\
\text { disorder) }\end{array}$ & & $\begin{array}{l}\text { bet, amount bet per } \\
\text { trial. }\end{array}$ & $\begin{array}{l}\text { manipulation (monetary } \\
\text { reward vs no monetary } \\
\text { reward) on the slot machine. }\end{array}$ & $\begin{array}{l}\text { no monetary reward } \\
\text { condition. There were no } \\
\text { further effects on other } \\
\text { dependent variables on } \\
\text { interactions with alcohol use } \\
\text { symptomology. }\end{array}$ \\
\hline \multicolumn{6}{|c|}{ Salience of Money } \\
\hline $\begin{array}{l}\text { McGrath } \\
\text { (2005) }\end{array}$ & $\begin{array}{l}\mathrm{N}=100 \\
\text { community } \\
\text { slot machine } \\
\text { gamblers, } \\
\text { grouped as no- } \\
\text { risk or low-risk } \\
\text { gamblers vs } \\
\text { moderate or } \\
\text { high-risk of } \\
\text { problem } \\
\text { gambling }\end{array}$ & PGSI & $\begin{array}{l}\text { Authentic slot machine, } \\
\text { deriving behavioural } \\
\text { measures of time spent } \\
\text { gambling, total amount } \\
\text { gambled, total number } \\
\text { of bets made, bets } \\
\text { made per minute, and } \\
\text { amount spent per } \\
\text { minute. }\end{array}$ & $\begin{array}{l}2 \times 2 \text { between-groups design } \\
\text { with slot machine payment } \\
\text { (coins or credits) and PGSI } \\
\text { category (no/low risk vs } \\
\text { moderate/high risk). In the } \\
\text { coin condition, the } \\
\text { participant entered the coins } \\
\text { into the slot machine; in the } \\
\text { credit condition, the funds } \\
\text { were pre-loaded. Secondary } \\
\text { analyses tested the impact } \\
\text { of the bonus rounds as a } \\
\text { potential confound. }\end{array}$ & $\begin{array}{l}\text { Significant main effects were } \\
\text { seen on the number of bets } \\
\text { per minute, and amount bet } \\
\text { per minute, which were } \\
\text { both higher in the credit } \\
\text { condition than participants } \\
\text { in the coin condition. These } \\
\text { effects were confirmed in } \\
\text { secondary analyses in only } \\
\text { participants who did not } \\
\text { encounter bonus rounds. A } \\
\text { further effect in the } \\
\text { opposite direction was seen } \\
\text { on the overall amount bet. } \\
\text { None of these effects } \\
\text { interacted with PGSI risk } \\
\text { group. }\end{array}$ \\
\hline $\begin{array}{l}\text { Weatherly et } \\
\text { al (2006) }\end{array}$ & $\begin{array}{l}\text { Expt 1: } N=36 \\
\text { Expt 2: } N=36\end{array}$ & SOGS & $\begin{array}{l}\text { Slot machine } \\
\text { simulation, deriving } \\
\text { several behavioural } \\
\text { measures including } \\
\text { total number of trials, } \\
\text { total points bet, number } \\
\text { of points remaining at } \\
\text { the end of session. }\end{array}$ & $\begin{array}{l}\text { Expt 1: between-groups } \\
\text { design with } 3 \text { salience } \\
\text { conditions. Each group plays } \\
\text { a slot machine for the same } \\
\text { monetary reward ( } 100 \text { credit } \\
\text { endowment worth } \$ 0.05 \\
\text { each), but Group } 1 \text { do not } \\
\text { see the cash; Group } 2 \\
\text { observe the researchers } \\
\text { holding a } \$ 10 \text { bill, and in }\end{array}$ & $\begin{array}{l}\text { Expt 1: Group } 3 \text { (participant } \\
\text { holds \$10) played fewer } \\
\text { trials and bet fewer credits. } \\
\text { Expt 2: Group } 1 \text { (less } \\
\text { valuable credits) played } \\
\text { significantly more trials than } \\
\text { Group } 2 \text { (more valuable } \\
\text { credits) or Group } 3 \text { (choice), } \\
\text { which did not differ. Most in }\end{array}$ \\
\hline
\end{tabular}




\begin{tabular}{|c|c|c|c|c|c|}
\hline & & & & $\begin{array}{l}\text { Group 3, the participants } \\
\text { hold the } \$ 10 \text { bill. } \\
\text { Expt 2: between subjects } \\
\text { design with } 3 \text { salience } \\
\text { instructions: } \\
\text { Group } 1 \text { endowed with } 100 \\
\text { credits worth } \$ 0.05 \text { each, } \\
\text { Group } 2 \text { endowed with } 20 \\
\text { credits worth } \$ 0.25 \text { each, } \\
\text { and Group } 3 \text { offered a choice } \\
\text { between Groups } 1 \text { and } 2 \text {. }\end{array}$ & $\begin{array}{l}\text { Group } 3 \text { opted to play with } \\
\text { the } 0.25 \text { cents option. } \\
\text { Groups did not differ in the } \\
\text { overall amount of money } \\
\text { they wagered due to the } \\
\text { differing points value. }\end{array}$ \\
\hline $\begin{array}{l}\text { Brandt \& } \\
\text { Martin (2015) }\end{array}$ & $\begin{array}{l}\mathrm{N}=40 \\
\text { students }\end{array}$ & SOGS & $\begin{array}{l}\text { Slot machine } \\
\text { simulation. The } \\
\text { behavioural measure } \\
\text { was the choice of a risky } \\
\text { task (gambling) versus } \\
\text { non risky task (working } \\
\text { for points). }\end{array}$ & $\begin{array}{l}\text { Between-subjects design } \\
\text { with a } 2 \text { (Endowment } \\
\text { Instruction) } \times 2 \text { (Balance } \\
\text { Reminders) design. } \\
\text { Participants received an } \\
\text { endowment of } 10 \text { credits } \\
\text { worth } 10 \text { cents each. The } \\
\text { enhanced endowment } \\
\text { instructions emphasized the } \\
\text { monetary value of the } \\
\text { tokens and showed a picture } \\
\text { of } 5 \times \$ 1 \text { bills. This was } \\
\text { crossed with one group who } \\
\text { viewed their balance } \\
\text { information after each block } \\
\text { versus the other group who } \\
\text { only viewed their balance at } \\
\text { the end of the task. }\end{array}$ & $\begin{array}{l}\text { The Balance Reminder was } \\
\text { associated with significantly } \\
\text { less risky choice (to gamble) } \\
\text { compared to the control } \\
\text { condition. No effect of } \\
\text { Endowment Instructions, } \\
\text { and no interaction between } \\
\text { Balance Reminders and } \\
\text { Endowment Instructions. }\end{array}$ \\
\hline $\begin{array}{l}\text { Limbrick- } \\
\text { Oldfield et al } \\
\text { (2021) }\end{array}$ & $\begin{array}{l}\text { Expt } 1: \mathrm{N}=61 \\
\text { community } \\
\text { slot machine } \\
\text { gamblers }\end{array}$ & PGSI & $\begin{array}{l}\text { Authentic slot machine, } \\
\text { deriving behavioural } \\
\text { measures of bet mean } \\
\text { size, total bet (session), }\end{array}$ & $\begin{array}{l}\text { Expt 1: participants } \\
\text { randomized to use slot } \\
\text { machine in 'cash' condition } \\
\text { (\$40 held and inserted into }\end{array}$ & $\begin{array}{l}\text { The 'session aggregated' } \\
\text { measures detected no } \\
\text { significant differences }\end{array}$ \\
\hline
\end{tabular}




\begin{tabular}{|c|c|c|c|c|c|}
\hline & $\begin{array}{l}\text { Expt 2: } \mathrm{N}=48 \\
\text { community } \\
\text { slot machine } \\
\text { gamblers }\end{array}$ & & $\begin{array}{l}\text { total bet (first } 5 \\
\text { minutes), balance at } \\
\text { session end. }\end{array}$ & $\begin{array}{l}\text { machine) or 'voucher' } \\
\text { condition (modelled on a } \\
\text { Ticket In/Ticket Out } \\
\text { voucher), but for equivalent } \\
\text { financial bonuses. } \\
\text { Expt 2: participants acquired } \\
\text { the } \$ 40 \text { cash endowment for } \\
\text { the slot machine session } \\
\text { through an earning } \\
\text { procedure, or as a windfall, } \\
\text { with both conditions playing } \\
\text { for equivalent financial } \\
\text { bonuses. }\end{array}$ & $\begin{array}{l}\text { between conditions in Expt } \\
1 \text { or Expt } 2 \text {. } \\
\text { In a secondary analysis using } \\
\text { a trial-level regression } \\
\text { approach, some behavioural } \\
\text { effects on speed of play and } \\
\text { bet size differed between } \\
\text { the conditions, but none of } \\
\text { these effects were } \\
\text { consistent across the two } \\
\text { experiments. }\end{array}$ \\
\hline \multicolumn{6}{|c|}{ RG Manipulations } \\
\hline $\begin{array}{l}\text { Loba et al } \\
\text { (2001) }\end{array}$ & $\begin{array}{l}\mathrm{N}=60 \text { regular } \\
\mathrm{EGM} \\
\text { gamblers; } 29 \\
\text { pathological } \\
\text { and } 31 \text { non- } \\
\text { pathological }\end{array}$ & SOGS & $\begin{array}{l}\text { Video Lottery Terminals } \\
\text { that offered one slot } \\
\text { machine game and one } \\
\text { video poker game, } \\
\text { configured to different } \\
\text { settings. Post-game } \\
\text { questionnaires assessed } \\
\text { excitement, enjoyment, } \\
\text { tension-reduction, and } \\
\text { difficulty stopping play. }\end{array}$ & $\begin{array}{l}\text { A } 2 \text { (points counter: counter } \\
\text { on, vs. counter off, } \\
\text { monetary) } x 2 \text { (gambler } \\
\text { status: pathological vs. non- } \\
\text { pathological, non-monetary) } \\
\text { x } 2 \text { (game: video poker vs. } \\
\text { spinning reels, non- } \\
\text { monetary) within-subjects } \\
\text { design was employed to test } \\
\text { the effect of an on-screen } \\
\text { points counter. }\end{array}$ & $\begin{array}{l}\text { Main effect of counter } \\
\text { manipulation on tension } \\
\text { reduction: less tension relief } \\
\text { (i.e. greater tension) in the } \\
\text { counter ON condition. } \\
\text { Counter x PG group } \\
\text { interaction on difficulty } \\
\text { stopping play: PG group } \\
\text { reported easier to stop play } \\
\text { in the Counter ON condition; } \\
\text { no effect in the non- } \\
\text { problem gamblers. }\end{array}$ \\
\hline $\begin{array}{l}\text { Blaszczynski et } \\
\text { al (2005) }\end{array}$ & $\begin{array}{l}\mathrm{N}=336 \\
\text { gambling } \\
\text { venue } \\
\text { patrons, } \\
\text { including } \\
\text { some with }\end{array}$ & SOGS & $\begin{array}{l}8 \text { modified but realistic } \\
\text { slot machines. Post- } \\
\text { game questionnaire } \\
\text { assessed satisfaction/ } \\
\text { enjoyment. }\end{array}$ & $\begin{array}{l}\text { Field study that involved } 8 \\
\text { modified slot machines in a } 2 \\
\text { (maximum bill accepted: } 20 \\
\text { vs } 100, \text { monetary) x } 2 \\
\text { (maximum bet: } \$ 1 \text { vs } \$ 10 \text {, } \\
\text { monetary) x } 2 \text { (game speed: } \\
3.5 \text { s vs } 5 \text { s, non-monetary) }\end{array}$ & $\begin{array}{l}\text { Main Effects: } \\
\text { For bill acceptors, there was } \\
\text { no effect on } \\
\text { enjoyment/satisfaction. } \\
\text { There was no effect of } \\
\text { reducing the maximum bet }\end{array}$ \\
\hline
\end{tabular}




\begin{tabular}{|c|c|c|c|c|c|}
\hline & $\begin{array}{l}\text { pathological } \\
\text { gambling }\end{array}$ & & & within-subjects design. & $\begin{array}{l}\text { (\$1 vs \$10) on participant's } \\
\text { ratings of satisfaction. } \\
\text { Interaction effects: } \\
\text { Participants with } \\
\text { pathological gambling } \\
\text { reported less enjoyment and } \\
\text { satisfaction overall, than } \\
\text { recreational gamblers. }\end{array}$ \\
\hline $\begin{array}{l}\text { Sharpe et al } \\
(2005)\end{array}$ & $\begin{array}{l}\mathrm{N}=779 \\
\text { patrons from } \\
\text { gambling } \\
\text { venues }\end{array}$ & $\begin{array}{l}\text { SOGS } \\
\text { (available } \\
\text { on } \mathrm{N}=634 \text { ) }\end{array}$ & $\begin{array}{l}8 \text { modified but realistic } \\
\text { slot machines. } \\
\text { Behavioural measures: } \\
\text { total bet amount, } \\
\text { number of bets placed, } \\
\text { money withdrawn, } \\
\text { session duration, use of } \\
\text { note acceptors, } \\
\text { cigarettes smoked, } \\
\text { alcoholic drinks } \\
\text { consumed, ATM visits. }\end{array}$ & $\begin{array}{l}\text { Field study that involved } 8 \\
\text { modified slot machines, as in } \\
\text { Blaszczynski et al 2005, but } \\
\text { in this study gamblers were } \\
\text { not assigned (randomized) to } \\
\text { the different machines; they } \\
\text { choose which machine to } \\
\text { play. Behaviour examined in } \\
\text { a } 2 \text { (maximum bill accepted: } \\
20 \text { vs } 100, \text { monetary) x } 2 \\
\text { (maximum bet: } \$ 1 \text { vs } \$ 10 \text {, } \\
\text { monetary) x } 2 \text { (game speed: } \\
3.5 \text { s vs } 5 \text { s, non-monetary) } \\
\text { design. }\end{array}$ & $\begin{array}{l}\text { Bill acceptors: no significant } \\
\text { differences. } \\
\text { Maximum bet (\$1 vs } \$ 10) \text { : } \\
\text { participants on } \$ 10 \\
\text { machines played longer } \\
\text { sessions, placed more bets, } \\
\text { sustained greater losses, } \\
\text { compared to those on the } \\
\$ 1 \text { machines. }\end{array}$ \\
\hline \multicolumn{6}{|c|}{ Free money promotions } \\
\hline $\begin{array}{l}\text { Challet-Bouju } \\
\text { et al (2020) }\end{array}$ & $\begin{array}{l}\mathrm{N}=171 \\
\text { internet } \\
\text { gamblers: half } \\
\text { were at risk, } \\
\text { half were non- } \\
\text { problem } \\
\text { gamblers. }\end{array}$ & PGSI & $\begin{array}{l}\text { Online gambling game } \\
\text { of the participants } \\
\text { choosing. Behavioural } \\
\text { measures of total } \\
\text { money wagered, } \\
\text { amount of time spent } \\
\text { gambling. Self-report } \\
\text { measures of internet }\end{array}$ & $\begin{array}{l}\text { Between-subjects design } \\
\text { with } 4 \text { levels of promotional } \\
\text { inducement (10, 50, 100, or } \\
200 \text { euros) and a control } \\
\text { condition with no } \\
\text { inducement. Participants } \\
\text { gambled on their preferred } \\
\text { online game for up to } 3 \\
\text { hours, in a laboratory. In the }\end{array}$ & $\begin{array}{l}\text { Main effect of inducement } \\
\text { amount for total money } \\
\text { wagered: increased bet } \\
\text { amount in the } € 100 \text { and } € \\
200 \text { conditions. } \\
\text { Increased GRCS Gambling } \\
\text { Expectancies in the } € 10 \text { and } \\
€ 50 \text { conditions. }\end{array}$ \\
\hline
\end{tabular}




\begin{tabular}{|c|c|c|c|c|c|}
\hline & & & $\begin{array}{l}\text { gambling attitudes and } \\
\text { cognitive distortions. }\end{array}$ & $\begin{array}{l}\text { inducement conditions, } \\
\text { participants received a "bank } \\
\text { e-card" in the middle of their } \\
\text { session, loaded with the } \\
\text { inducement amount. } \\
\text { Cognitive distortions were } \\
\text { measured after the gambling } \\
\text { session. }\end{array}$ & $\begin{array}{l}\text { Participants in the } € 200 \\
\text { inducement condition } \\
\text { reported a significantly } \\
\text { higher degree of loss of } \\
\text { control after the session. } \\
\text { No effect of inducement on } \\
\text { time spent gambling. } \\
\text { No significant interaction } \\
\text { effects with gambling status. }\end{array}$ \\
\hline $\begin{array}{l}\text { Kim et al } \\
(2021)\end{array}$ & $\begin{array}{l}\mathrm{N}=234 \\
\text { gamblers with } \\
\text { experience of } \\
\text { social casino } \\
\text { games }\end{array}$ & PGSI & $\begin{array}{l}\text { Online roulette task } \\
\text { deriving behavioural } \\
\text { measures of decision to } \\
\text { play or not, total } \\
\text { number of roulette } \\
\text { spins, highest single } \\
\text { wager, and total } \\
\text { number of credits } \\
\text { wagered. }\end{array}$ & $\begin{array}{l}\text { Between-subjects design } \\
\text { with two conditions on an } \\
\text { initial free-to-play slot } \\
\text { machine simulation. Both } \\
\text { groups were compensated a } \\
\text { max of } \$ 7 \text { for their } \\
\text { participation, but } \\
\text { participants in the bonus } \\
\text { condition receive a further } \\
\text { \$1-\$5 depending on credits } \\
\text { earned in the free-to-play } \\
\text { game. The control condition } \\
\text { received no bonus. } \\
\text { Participants were then } \\
\text { invited to play an online } \\
\text { roulette game with funds } \\
\text { earned. }\end{array}$ & $\begin{array}{l}\text { On the roulette game, there } \\
\text { were no significant } \\
\text { differences between } \\
\text { conditions in the decision to } \\
\text { gamble. Among those who } \\
\text { decided to gamble, there } \\
\text { were no significant } \\
\text { differences between groups } \\
\text { for any of the dependent } \\
\text { variables. Participants in the } \\
\text { bonus condition placed } \\
\text { more bets and higher bet } \\
\text { amounts than the control } \\
\text { condition on the free-to- } \\
\text { play game itself. }\end{array}$ \\
\hline
\end{tabular}

SOGS = South Oaks Gambling Screen. PGSI = Problem Gambling Severity Index. CPGI = Canadian Problem Gambling Index. GRCS = Gambling Related Cognitions Scale. ATM = automatic teller machine. PET = Positron Emission Tomography. 
Identification of studies via databases and registers

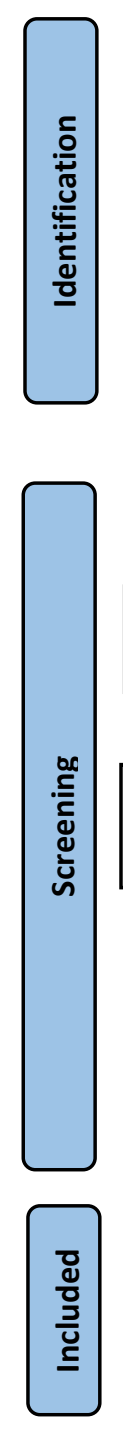

Records identified from databases through 1990 to

September 2021:

PubMed $(n=2157)$

Psyclnfo $(n=1777)$

Grey literature records identified

through 1990 to September

2021:

GREO $(n=35)$

ProQuest $(n=833)$

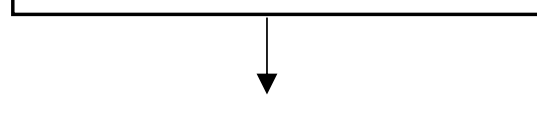

Records screened

$(\mathrm{n}=3996)$

\begin{tabular}{|c|c|c|}
\hline $\begin{array}{l}\text { Reports sought for retrieval } \\
(n=31)\end{array}$ & $\longrightarrow$ & $\begin{array}{l}\text { Reports not retrieved } \\
(n=N A)\end{array}$ \\
\hline
\end{tabular}

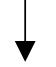

Reports assessed for eligibility $(n=31)$

\section{Reports of included studies}

$(n=19)$
Records excluded

$(n=3965)$

\section{Identification of studies via other methods}

Records identified

from:

Websites ( $n=5)$

Citation searching

$(\mathrm{n}=2)$

Other $(n=1)$

removed

$(n=806)$

$(n=N A)$

Reports excluded:

No Gambling Screen $(n=8)$

No Gambling Task ( $n=1)$

No Money Manipulation

$(n=6)$

Ineligible DV $(n=1)$
Reports not retrieved

$(n=N A)$

retrieval

$(n=8)$

Reports excluded:

No Gambling

Screen $(n=2)$

No Gambling Task

$(n=2)$ 


\section{Supplementary Material for Palmer, Cringle \& Clark 'A scoping review of experimental manipulations examining the impact of monetary format on gambling behaviour'}

Inclusion/Exclusion Criteria:

This scoping review is concerned with exploring the types of studies researchers have conducted to study monetary manipulation in gambling games. Particularly, we are interested in the various experimental methods researchers have employed in the past to manipulate monetary format in a variety of gambling games. Through this scoping review we hope to determine the potential implications of emerging monetary formats in gambling on gambling harms. We have determined four inclusion/exclusion criteria for selecting studies for this review:

1) a study must have included a measure of gambling severity, e.g. PGSI or SOGS. In order to relate the impact of monetary manipulations to disordered gambling or gambling harms, the sample need to be characterized in terms of gambling involvement.

2) the study must have used a gambling scenario that adheres to psychological definitions of gambling (e.g. Reber 2012), i.e. a consideration (bet or stake) on a chance outcome for a larger prize. This decision excludes studies using cognitive tasks such as delay discounting, the lowa Gambling Task, or the Balloon Analogue Risk Task, which are validated neurocognitive probes of value-based or risk-based decision making, but do not formally model the act of gambling (e.g., the lowa Gambling Task does not involve a bet)

3) As dependent variables, the study must have measured gambling behaviour (e.g., amount or money bet or number of bets), subjective measures of gambling experience (e.g., self-reported arousal), or physiological measures (including both peripheral psychophysiology such as heart rate, or brain imaging measures)

4) As the independent variable, the study needs to be an experimental design with at least two groups (i.e., including a control condition), employing what we define as a monetary manipulation. Here, we were careful to differentiate a monetary manipulation from related 'structural characteristics' broadly pertaining to the rate or intensity of wins or reinforcement, such as jackpot size or return to player. Monetary manipulations would include studies that i) examine the presence of money in a gambling game (i.e. in comparison to playing the same game with hypothetical prizes, or making predictions without financial outcomes), ii) examine the format of money in the game (e.g. betting using cash versus some form of credit, or wins paid as cash vs vouchers, where in both conditions the objective financial value is equivalent). Notably, we included field designs if appropriate control conditions were present; for example, if casino slot machines were modified to present financial information in different ways. As a scoping exercise, we viewed our objective as using our search to characterise the different kinds of research designs that existed to examine monetary factors, and for this reason we were not prescriptive with the exact kinds of manipulation that would be included. 


\section{Psyclnfo Search String:}

TI ( (gambl* OR (egm OR electronic gaming machine* OR slot machine* OR structural characteristic*)) AND (money OR monetary OR payment OR cash OR credit OR note acceptors OR bill acceptors OR win*)) OR AB ( (gambl* OR (egm OR electronic gaming machine* OR slot machine* OR structural characteristic*)) AND (money OR monetary OR payment OR cash OR credit OR note acceptors OR bill acceptors OR win*))

\section{PubMed Search String:}

(((gambling[MeSH Terms]) OR (gambl*) OR (egm OR electronic gaming machine* OR slot machine* OR structural characteristic*))) AND (money OR monetary OR payment OR cash OR credit OR note acceptors OR bill acceptors OR win)

\section{ProQuest Search String:}

(ab(gambl* OR (egm OR "electronic gaming machine*" OR ("slot machine" OR "slot machines") OR ("structural characteristic" OR "structural characteristics"))) AND ab(money OR monetary OR payment OR cash OR credit OR "note acceptors" OR "bill acceptors" OR win*)) OR (ti(gambl* OR (egm OR "electronic gaming machine*" OR ("slot machine" OR "slot machines") OR ("structural characteristic" OR "structural characteristics"))) AND ti(money OR monetary OR payment OR cash OR credit OR "note acceptors" OR "bill acceptors" OR win*))

\section{Gambling Research Exchange Ontario (GREO) String:}

gambl* OR (egm OR "electronic gaming machine*" OR ("slot machine" OR "slot machines") OR ("structural characteristic" OR "structural characteristics"))) AND (money OR monetary OR payment OR cash OR credit OR "note acceptors" OR "bill acceptors" OR win*))

\section{Twitter Call for papers wording:}

"Gambling research tweeps! CGR is currently conducting a scoping review of experimental studies on monetary format \& effects on gambling. Please reply or DM if you have recent studies, grey lit, or unpublished work that may be suitable. Further details in thread. Thanks!

Criteria. The easy ones: 1. Includes gambling screen, 2 . uses a gambling scenario (real or simulated, but not cog tests like IGT, discounting). 3. dv must measure gambling experience, bhv or physiology. Lastly, the more complicated one: 4. study must use an experimental design (field or lab) to assess a 'monetary manipulation' e.g. presence/absence of $\$$, format of $\$$ (cash vs credit), or display. We're keen to identify different relevant designs, but distinct from other features like reward size, rate, RTP." 